

\title{
PENGARUH LATIHAN KELINCAHAN TEHADAP KEMAMPUAN MENGGIRING PEMAIN SEPAK BOLA KLUB LEPARISSA AMALATU KABUPATEN SERAM BAGIAN BARAT
}

\author{
Isnan Ukratallo' Bahmid Hasbullah² \\ bahmidhasbullah@gmail.com
}

\begin{abstract}
Abstrak
Sepak bola merupakan permainan yang membutuhkan teknik, kekompakan dan kerja sama. Penguasaan terhadap teknik-teknik dasar akan mencerminkan tingkat keterampilan pemain sepakbola yang bersangkutan. Keterampilan fisik yang dimaksud adalah kekuatan, kecepatan, kelincahan, kelentukan, keseimbangan, juga daya tahan,. Latihan kelincahan sangatlah penting, karena yang dibutuhkan pada saat menggiring bola bagaimana atlet mampu menghindari diri dari hadangan lawan dengan posisi masih menguasai dan mempertahankan bola tanpa hilangnya keseimbangan, dengan lokasi penelitian di club Alba Batu Mera. Penelitian ini mengunakan metode kuantitatif dengan pendekatan eksperimen lapangan dengan desain penelitian one grop test - post test. Berdasarkan hasil pengujian hipotesis dalam penelitian ini diketahui terdapat pengaruh latihan kelincahan terhadap kemampuan memggiring pada pemain sepak bola klub Alba Batu Maerah Ambon. Hal ini menunjukan bahwa latihan kelincahan dapat memberikan pengaruh yang kuat pada kemampuan menggiring sangat baik sehingga dapat dijelaskan bahwa latihan kelincahan merupakan salah satu alternatif yang dapat digunakan untuk meningkatkan kemampuan menggiring.
\end{abstract}

Kata Kunci : Sepak Bola, Kelincaan, Menggring Bola

\begin{abstract}
Football is a game that requires technique, cohesiveness and cooperation. Mastery of basic techniques will reflect the skill level of the football player concerned. Physical skills in question are strength, speed, agility, flexibility, balance, and endurance. Agility training is very important, because what is needed when dribbling is how athletes are able to avoid themselves from opposing opponents while still controlling and maintaining the ball without losing balance, with the research location at the Alba Batu Mera club. This study uses a quantitative method with a field experiment approach with a one-grop testpost test research design. Based on the results of hypothesis testing in this study, it is known that there is an effect of agility training on the ability of the Alba Batu Merah Ambon club soccer player. This shows that agility training can have a strong influence on the ability to dribble very well so that it can be explained that agility training is an alternative that can be used to improve the ability to dribble.
\end{abstract}

Keywords: Soccer, Agility, Grading the Ball

\section{PENDAHULUAN}


Sepak bola merupakan permainan yang membutuhkan teknik, kekompakan dan kerja sama. Sepak bola bukan permainan yang bersifat perseorangan akan tetapi merupakan permainan yang bersifat beregu. regu terdiri dari 11 orang, sehingga harus ada kerja sama antara pemain untuk menghasilkan kemenangan juga sepak bola merupakan salah satu cabang olah raga yang menuntut setiap pemain menguasai berbagai macam teknik dasar seperti passing, stopping, juggling, dribbling, heading, dan shooting. Tujuan dari permainan sepak bola adalah pemain memasukan bola sebanyak-banyaknya ke gawang lawannya dan berusaha menjaga gawangnya sendiri, agar tidak kemasukan. (Sucipto, 2001)

Penguasaan terhadap teknik-teknik dasar akan mencerminkan tingkat keterampilan pemain sepakbola yang bersangkutan. Permainan Sepak bola tidak hanya memerlukan keterampilan tetapi juga harus memerlukan kekuatan, kecepatan, kelincahan, kelentukan, keseimbangan, juga daya tahan, misalnya bukan hanya keterampilan dalam menggiring bola tetapi unsur kelincahan juga harus diperhatikan. Menurut (Mihardja et al., 2001) kelincahan (agility) adalah kemampuan tubuh untuk mengubah arah secara cepat tanpa adanya gangguan keseimbangan atau kehilangan keseimbangan. Dengan memiliki tingkat kelincahan maka kecepatan kaki untuk mengubah posisi dalam menentukan arah laju bola juga baik sehinga pada kaki tumpu dalam pergerakan nantinya akan lebih mudah dalam melakukan tumpuan dan menentukan arah bola.

Latihan kelincahan sangatlah penting, karena yang dibutuhkan pada saat menggiring bola bagaimana atlet mampu menghindari diri dari hadangan lawan dengan posisi masih menguasai dan mempertahankan bola tanpa hilangnya keseimbangan, sehingga mampu masuk kedalam daerah pertahanan lawan dan bisa menciptakan sebuah peluang untuk memasukan bola ke gawang lawan.

Kebiasaan yang sering di lakukan Klub sepak bola Alba Negeri batu merah yaitu dalam proses latihannya terlalu mengutamakan latihan menendang, mengoper dan menahan bola berhubung kondisi atlit masih pada tingkatan usia 13-15 tahun. Sementara yang di butuhkan dalam sepak bola bukan hanya kemampuan menendang, mengoper dan menahan bola tetapi di imbangi dengan kemampuan menggiring bola yang baik.

Terkait dengan itu pada Klub sepak bola Alba ketika atlet menggiring bola masih terlihat kurang. Kelincahan atlet dalam memainkan bola untuk menghindari diri dari hadangan lawan dan memepertahankan bola pada saat bermain masih kurang sehingga bola gampang direbut oleh pemain lawan, maka sepantasnya atau sudah saatnya pelatih melihat kesenjangan yang terjadi antara fakta teoritis dan fakta impiris yang dialami dan mungkin menjadi faktor kegagalan pemain dalam mempertahankan penguasaan bola pada saat menggiring bola di dalam lapangan baik pertandingan maupun persahabatan yang akan dilakukan.

tujuan penelitian ini adalah untuk mengetahui ada tidaknya pengaruh latihan kelincahan terhadap kemampuan menggiring pada pemain klub sepak bola Alba Ambon. Sehingga sasaran penelitian ini mengarah pada kajian berapa besar pengaruh latihan kelincaan terhadap kemampuan mengiring bola.

\section{METODE}

Penelitian ini mengunakan metode kuantitatif dengan pendekatan eksperimen lapangan dengan desain penelitian one grop test - post test menurut (Sutisyana \& Ilahi, 2017) sebagai berikut :

\begin{tabular}{l|l|l}
\hline $\mathrm{T} 1$ & $\mathrm{X}$ & $\mathrm{T} 2$ \\
\hline
\end{tabular}


Gambar 1. Disain Pre test Dan Post test (Sutisyana \& llahi, 2017) Keterangan Gambar :

T1 = Tes awal

$X=$ Latihan kelincahan

$\mathrm{T} 2=$ Tes akhir

Sehingga hasil yang diperoleh dapat memperoleh keadaan yang sebenarnya dari masalah yang dihadapi.

Tempat penelitian adalah klub sepak bola Alba Negeri Batu Merah kecamatan Sirimau Kota Ambon Maluku. Sampel dalam penelitian ini adalah pemain putra yang berjumlah 20 orang diambil secara random sampling. Untuk mendapatkan data digunakan maka teknik pengumulan data untuk tes kemampuan menggiring bola) dan latihan kelincaan dengan indikator shuttle run dan zig-zag run. (Nurhasan, 2000). Setelah data terkumpul kemudian diolah secara statistik dengan menggunakan uji $t$. yang perlu ditempuh dalam rangka memperoleh harga $t_{0}$ berut-turut adalah sebagai berikut. (Anas, 2009)

Keterangan :

$$
\text { to }=\frac{M_{D}}{S E_{M_{D}}}
$$

MD Mean of Difference Nilai Rata-rata Hitung dari Beda/Selisih antara Skor Variabel I dan Skor Variabel II, yang dapat diperoleh dengan rumus:

$$
M_{D}=\frac{\sum D}{N}
$$

$\Sigma \mathrm{D} \quad=\quad$ Jumlah Beda/Selisih antara Skor Variabel I (variabel X) dan Skor Variabel II (Variabel $Y)$, dan $D$ dipat diperoleh dengan rumus:

$\mathrm{D}=\mathrm{X}-\mathrm{Y}$

$\mathrm{N}=$ Number of Cases $=$ Jumlah Subjek yang kita teliti

$S E_{M_{D}}=$ Standard Error (Stander Kesesatan) dan Mean of Difference yang dapat diperoleh dengan rumus:

$S E_{M_{D}}=\frac{S D_{D}}{\sqrt{N-1}}$

$\mathrm{SD}_{\mathrm{D}}=$ Deviasi Standar dari Perbedaan antara Skor Variabel I dan skor Variabel II, yang dapat diperoleh dengan rumus:

$S D_{D}=\sqrt{\frac{\sum D^{2}}{N}-\left(\frac{\sum D}{N}\right)^{2}}$

$\mathrm{N}=$ Number of Cases.

\section{HASIL DAN PEMBAHASAN}

Berdasarkan penelitian yang disaji dalam tabel Data yang diperoleh dan dianalisis dalam penelitian ini meliputi, data tes awal (Pree-Test) dan tes akhir (Post Test) dari kemampuan menggiring. Setelah semua data dikumpulkan, maka data-data tersebut disajikan dalam table sebagai berikut :

Tabel 1

Tabel Distribusi hasil tes kemampuan menggiring bola 


\begin{tabular}{ccccc}
\hline No & $X$ & $Y$ & $D(X-Y)$ & $D^{2}(X-Y)^{2}$ \\
\hline 1 & 24 & 21 & 3 & 9 \\
\hline 2 & 32 & 30 & 2 & 4 \\
\hline 3 & 23 & 20 & 3 & 9 \\
\hline 4 & 24 & 23 & 1 & 1 \\
\hline 5 & 34 & 29 & 5 & 25 \\
\hline 6 & 23 & 21 & 2 & 4 \\
\hline 7 & 22 & 19 & 3 & 9 \\
\hline 8 & 29 & 25 & 4 & 16 \\
\hline 9 & 26 & 24 & 2 & 4 \\
\hline 10 & 26 & 23 & 3 & 9 \\
\hline 11 & 25 & 23 & 2 & 4 \\
\hline 12 & 30 & 26 & 4 & 16 \\
\hline 13 & 32 & 29 & 3 & 9 \\
\hline 14 & 31 & 29 & 2 & 4 \\
\hline 15 & 21 & 20 & 1 & 1 \\
\hline 16 & 29 & 26 & 3 & 9 \\
\hline 17 & 31 & 28 & 3 & 9 \\
\hline 18 & 33 & 30 & 3 & 9 \\
\hline 19 & 22 & 20 & 2 & 4 \\
\hline 20 & 27 & 25 & 2 & 4 \\
\hline $\mathrm{N}=15$ & $\sum \mathrm{X}=544$ & $\sum \mathrm{Y}=491$ & $\sum \mathrm{D}=53$ & $\sum \mathrm{D}^{2}=159$ \\
\hline & & & &
\end{tabular}

Hasil analisis data antara varibel $X$ dengan variabel $Y$ adalah :Berdasarkan hasil perhitungan dapat dilihat thitung $=11.990$ kemudian dikonsultasikan dengan angka kritik data tabel baik pada taraf signifikasi $5 \%$ maupun $1 \%$ dengan terlebih dahulu menentukan db atau df-nya dimana db atau $\mathrm{df}=\mathrm{N}-1=20-1$ $=19$. Untuk taraf signifikasi $5 \%$ diketahui nilai tabel $=1.729$. Sedangkan untuk taraf signifikan $1 \%$ diketahui nilai $t_{\text {tabel }}=2.539$. Itu berarti baik pada taraf signifikan $5 \%$ maupun $1 \%$ nilai $(5 \%)$ $t_{\text {tabel }}<t_{\text {hitung }}>t_{\text {tabel }}=(1 \%)$ atau dengan kata lai dapat disimpulkan bahwa $1.729<11.990>2.539$.

Berdasarkan kriteria pengujian hipotesis jika $t_{\text {nitung }}>t_{\text {tabel }}$ maka hipotesis alternative atau $\mathrm{H}_{a}$ diterima dan sebaliknya menolak $\mathrm{H}_{0}$ atau hipotesis nihil. Dari pengujian diatas maka dapat disimpulkan bahwa hipotesis alternatif diterima dan secara jelas menerangkan bahwa latihan kelincahan memberikan pengaruh terhadap kemampuan menggiring bola.

Berdasarkan hasil pengujian hipotesis dalam penelitian ini diketahui terdapat pengaruh latihan kelincahan terhadap kemampuan memggiring pada pemain sepak bola klub Alba Batu Maerah Ambon. Hal ini menunjukan bahwa latihan kelincahan dapat memberikan pengaruh yang kuat pada kemampuan menggirirng sangat baik sehingga dapat dijelaskan bahwa latihan kelincahan merupakan 
salah satu alternatif yang dapat digunakan untuk meningkatkan kemampuan menggiring. Hasil ini dapat dicapai melalui perencanaan program latihan yang disusun secara objektif dan sistematis berdasarkan kemampuan tiap-tiap atlet sehingga mendapat hasil yang maksimal dalam menunjang prestasi atlet.

\section{DAFTAR PUSTAKA}

Anas, S. (2009). Pengantar Statistik Pendidikan. Rajawali Pres.

Mihardja, L., Adimunca, C., Widowati, L., Raflizar, R., Pujiastuti, P., Winarno, W., \& Wahjoedi, B. (2001). Manfaat Ekstrak Etanol Patikan Kebo (Euphorbia Hirta L.) Sebagai Laktagogum Pada

Tikus Putih Yang Menyusui. Indonesian Bulletin Of Health Research, 29(3), 66366.

Nurhasan. (2000). Pengembangan Sistem Pembelajaran. Fpok Upi Bandung.

Sucipto, E. D. Y. (2001). Hubungan Karakteristik Dan Keinginan Punya Anak Dengan Pemilihan

Kontrasepsi Di Desa Pedeslohor Kecamatan Adewena Kabupaten Tegal Tahun 2000.

Diponegoro University.

Sutisyana, A., \& llahi, B. R. (2017). Pengaruh Metode Latihan Plyometric Terhadap Kemampuan Jumping Smash Bola Voli Siswa Ekstrakurikuler Smpn 1 Bermani Ilir Kabupaten Kepahiang. Kinestetik: Jurnal IImiah Pendidikan Jasmani, 1(1), 64-67. 